\title{
DIVISIVENESS AMONG MUSLIMS IN NIGERIA AND ITS IMPLICATIONS FOR NATIONAL INTEGRATION
}

\author{
Rafiu Ibrahim Adebayo*
}

\begin{abstract}
One of the factors responsible for the rapid spread of Islam throughout Nigeria, described as reminiscent of "burning grassland during Harmattan," was the role played by different Sufi Orders, which strove tirelessly to plant the religion wherever it had not previously reached. But this initial blessing to the religion engendered a divisive syncretism, to the extent that the centre could no longer hold, and things fell apart. This paper examines divisiveness among Muslims in Nigeria and the factors responsible for divisiveness. It suggests that for national integration to be achieved in Nigeria, Muslims in the country need to re-orient themselves to the Islamic concept of unity and brotherhood.
\end{abstract}

\section{Introduction}

Although the history of mankind is replete with incidences of divisions and violence against each other, the strong message of the Qur'an and the teachings of Prophet Muhammad (peace be upon him) are towards unity and brotherhood.

And hold fast all together, by the rope of Allah, and be not divided among yourselves; and remember with gratitude Allah's favour on you; for you were enemies and $\mathrm{He}$ joined your hearts in love, so that by His Grace, you became brethren (Qur'an 3:103).

All too common incidences of disunity can be cited such as the murderous despatch of Habil (Abel) by Qabil (Cain), the disputes and divisions of the Israelites in the Sinai with Prophet Musa (Moses AS), and the deep divisions in the Muslim ummah caused at the time of the murder of the third caliph 'Uthman (RA). Raheem highlights some of the effects of this incident on the Muslim community, among which are the creation of disunity and division between the Umayyads and the Hashimides, setbacks in the hitherto rapid spread and expansion of the Muslim empire, the reversal of ascendancy of the city of Madinah, and the beginning of a series of civil wars in the Muslim body politic. These wars consequently led to the assassination of 'Ali (RA), the Karbala tragedy involving the assassination of Husayn (RA), the grandson of Prophet Muhammad (PBUH), and the emergence of schism in Islam. ${ }^{1}$

The above historical precursors for divergences in the Ummah have weakened the strength of Muslims throughout the world. Unfortunately, Nigeria is one of the countries which have witnessed a series of religious crises and riots. Muslims 
here have also witnessed serious intra-religious misunderstandings within themselves. This paper therefore plans to assess some instances of divisiveness among Nigerian Muslims with a view to understanding the implications concerning national integration.

\section{Nigerian Muslims and Challenges of Diversity}

With the spread of Islam on Nigerian soil, a spirit of brotherhood and unity was inculcated among its adherents. Unfortunately, this sense deteriorated to the point of enmity among them. A major reason for this development was the high level of syncretism flourishing among them. Dissatisfied with this situation, Shaykh Uthman b. Fudio launched a jihad for the purpose of extricating Muslims from un-Islamic practices promoted by their Sufi leaders, who claimed to be Muslims. The jihad was initially successful and achieved its purpose, but an extension of jihad to the northeastern Borno territory was met with opposition from the Islamic scholar and political leader Shaykh Muhammad El-Kanemi (1776-1837). The exchange of words between the Sokoto Jihadists and Shaykh El-Kanemi helped in no small measure develop a dichotomy amongst Nigerian Muslims. A tussle over orthodoxy between them began with the attempt of the jihadists to capture Borno. El-Kanemi could not see any justifiable reason for a Muslim to take up arms against another Muslim community in Borno, a Muslim community. He recognised the perpetuation of social ills in Borno but saw that they were not peculiar to it, and as such were insufficient reason for Borno to be tagged a kafir community and attacked. He also accused the Mujahidin of infidelity, for handling the Holy Book of Allah carelessly. He concluded that the jihad was meant only for attaining political hegemony over another community and had no religious purpose.

Shaykh Uthman b. Fudio and his son, Muhammad Bello, however, reacted harshly to the allegation levied against the jihadists by El-Kanemi, and accused him of tribalism and weakness in taking no steps to correct the un-Islamic practices of his people. Although the two parties consequently agreed to live peacefully with each other, the incident was said to have led to the emergence of two separate and autonomous Islamic communities. ${ }^{2}$

Abdul Fattah identifies two major consequences of the prevention of the jihad from reaching and overtaking Borno as championed by Shaykh El-Kanemi: first, the prevention of the fusion of the whole North in particular and Nigeria in general into one community of Muslims living under Islamic law; and second, continuity of the overt existence of local customs which are antithetical to Islam, not only among the Borno populace but also among the ruling class of the Muslim community. ${ }^{3}$ 
Despite the above setting, the emergence of Sufism could be seen in a positive light in Nigeria, as it was a vehicle for the propagation of Islam in the nation. The members of any tariqah were taught a high sense of loyalty to the leadership and other members of the brotherhood. The relevance of the tariqah in Nigeria is aptly stated by Abdul Fattah thus:

There is no gain-saying the Sufi orders have at different times, especially at the beginning of Sufism, assisted in returning people who hitherto have gone astray back into the fold of Islam. Many Muslims who were in obeisance to the devil were tamed through the supplication, asceticism and seclusion taught by the Sufi orders. Human passions and urges were also said to be tamed by some of the practices of the Sufis. Sufism emphasizes close ties between members and so assisted in engendering an unreserved spirit of brotherhood among its adherents. Another sphere of interest relating to the Nigerian scene is that it has in the past drawn and sustained some sets of unbelievers into the fold of Islam. This may not be unconnected with its ecstatic nature of worship or the claim of sure acceptance of prayers often made by Sufi scholars. ${ }^{4}$

In spite of the numerous achievements of Sufi brotherhoods in Nigeria, the rivalry for supremacy among Sufi brotherhoods has undermined their standing. It is generally believed that the Qadiriyyah brotherhood came to Nigeria before the Tijaniyyah brotherhood. However, members of the Qadiriyyah transferred enmasse to the Tijaniyyah tariqah when they discovered that spiritual development in the Tijaniyyah brotherhood was much easier than in the Qadiriyyah. The Qadiriyyah leadership took steps to check this unpardonable development. The Waziri Gidado Dan Lema was said to have ordered the halt of movement of murids from the Qadiriyyah to the Tijaniyyah order, and non-compliance with this command of the Waziri consequently led to the exile of Lawal Kwasau (1897-1902) and Aliyu (1903-1920), the two successive Emirs of Zaria, to Lokoja. The seeds of discord between the Tijany and the Qadiry were said to have been planted in Ilorin during the tenure of Emir Ali, who was a Qadiry (1869-1891). A report revealed that the Emir ordered the beating of one Mallam, ${ }^{5}$ Muhammad Wali, a native of Ilorin who introduced the Tijaniyyah order to the city. The mallam was said to have died shortly after the beating. ${ }^{6}$

Apart from the cacophony or rivalry and internal conflict within the Sufi orders, and in spite of the successes of the orders in the propagation of Islam in Nigeria, the brotherhoods further encountered bitter opposition from some scholars who saw the teachings of the tariqah as un-Islamic. These last vehemently criticised some claims and practices of the tariqahs, such as the virtues attributed to recitation of salatul-fatih and Jawharatul-Kamal, excessive veneration of the Prophet and the Sufi shuyukh, the celebration of Maulud in-nabiyy as well as the practice of spreading a white cloth during the wird of the Tijaniyyah order. 
The emergence of the Jama' atul Izalatil-Bid'ah wa-Iqamatis-Sunnah popularly called the Yan Izalah in the seventies marked another serious campaign against Sufi orders in Nigeria. The activities of this body have had damaging effects on the Muslim community in Nigeria. A study of this group and its activities in Nigeria has been carried out by Qadri. Some of the effects of the Izalah on the ummah in Nigeria include:

1. Divisions: the Muslim community at Eid became divided. The Pro-Izalah members used the central mosque, while the Tariqah people were chased out of the mosque as they were regarded as kafir. The Imam of the mosque had to renounce his membership of Tijaniyyah for him to retain his imamship.

2. In Funtua, the Imam, Mallam Muhammad Mustafa Jibril, had to renounce his membership of the Tijaniyyah and join the Izalah. The Council of Mallams in the town was not happy with this development as well as his allowing the Izalah mallams to preach against Sufism in the central mosque; hence he was removed and the Izalah mallams were banned from preaching in any mosque in Funtua.

3. Where the Izalah people were not given a free hand to operate, they resorted to establishing their own mosques. Where they were not allowed to establish one, as happened in Zaria and Bauchi, they chose the house of their mallams as a substitute mosque.

4. The Izalah and the Tariqah started to arm themselves, inflicting bodily injuries on one another, not reflecting on the saying of the Prophet that "when two Muslims draw swords against each other, each one of the two would be an inmate of the hell-fire."7 This led to clashes which caused public disorder with loss of lives. ${ }^{8}$

In addition to the above, the operating system of the Tablighi Movement seems offensive to some tariqah members. Some Sufi leaders so detest the da' wah approach of the Tablighi Movement ${ }^{9}$ that they publicly condemn them. There was an occasion of Maulud of a Tijaniyyah Order in Ila-Orangun, a town in Osun State, where a prominent Sufi Shaykh from Offa gave an unfounded fatwah that any member of the Order whose child decided to join the Tablighi Movement should have such a child killed, and that such killing would attract special reward in Allah's sight.

The case of moon sighting for the commencement and termination of the fast has also generated hot debate amongst religious scholars in Nigeria. What is surprising is that there are differences in the commencement of the fast based on tribal sentiment. While the Supreme Council for Islamic Affairs under the headship of the Sultan of Sokoto calls for people to be watchful of the crescent and to inform the authority upon sighting it, the Muslims of the Southwest under the 
tutelage of the League of Imams and Alfas simply announce the commencement of the fast while giving little weight to the sighting of the crescent. This has exposed Muslims to ridicule by non-Muslims when such matters could have been resolved amicably in the name of unity. A misunderstanding regarding the sighting of the moon between the leadership of Zumratul Muminin in Ila-Orangun and the immediate past Chief Imam of the town resulted in the separation of the Zumratul-Muminin from the mainstream Muslim community and its decision to have its own separate Juma'at mosque and Eid praying ground.

As vexing as the problem of moon sighting may be, it is even more disheartening to see the Muslim Congress and the Organization of TadhamunulMuslimeen distancing themselves from the Muslim Students' Society of Nigeria due to conflicting ideas:

Disunity in the Muslim world in the contemporary period is equally evident in the many sectarian, theological and tribal conflicts that now dot the landscape of Muslim States in the East. From Somalia to Sudan and from Baghdad to Sana'a and unto Islamabad, the Muslim world cuts a picture of a house of ironies and paradoxes; a locus of crises and calamities. Ordinary citizens of these States stand more chances of being killed by their brethren than they do by the enemies of Islam. ${ }^{10}$

Due to the lack of unity amongst the Nigerian Muslims, some issues which could have been of benefit to the nation have eluded the country and Muslims, as they could not talk with one voice. Nigerian membership in the Organisation of Islamic Co-operation has not taken the country anywhere because Muslims who could have spoken out decided to keep quiet while the Christians were mounting serious opposition. The cacophony against the non-interest banking system by the Christians is another instance of Muslims being on trial in Nigeria. Except for some individuals who tried to educate the uninformed about the banking system, no Muslim body came out to enlighten the people. The attachment of Muslims to Boko Haram uprisings and their indifferent attitude to numerous insinuations made by the media is perhaps another by-product of Muslim disunity in the country. In the realm of education, Muslims could not raise their voices as they could not compete with their Christian counterparts in tertiary education, where, of the existing fifty private universities in Nigeria, the percentage owned by Muslim groups and individuals is insignificant. Muslims are also nowhere to be found in terms of proprietorship of media houses, be it print or electronic media. They are therefore voiceless and cannot air their opinions on any national issue.

Nevertheless, many Islamic organisations were created for the purpose of uniting the Ummah in Nigeria. These have succeeded only in creating more divisions than ever, however. Different umbrella organisations like the National 
Council of Muslim Youth Organisations (NACOMYO), the Federation of Muslim Women's Associations of Nigeria (FOMWAN), the National Joint Muslim Organisations (NAJOMO) and the like, were also put in place. These organisations achieved minimal success due to "egoism resulting in a proliferation of umbrella organisations; the divide between Muslim elites and the Imams and Alfas; a lack of buy-in and ownership; parochialism, ethno-centrism and intolerance; personality conflicts and ineffective conflict-resolution mechanisms." ${ }^{11}$ However, the Muslim Ummah of South West Nigeria (MUSWEN) was inaugurated on 10 August 2008 as a "product of a renewed concern for the lack of unity and absence of a generally acceptable leadership among the Muslims of the South West Nigeria." 12 As laudable as this idea is, one prays that this does not create a gap between the Muslim south and their counterparts in the northern part of the country, as an unintended consequence.

\section{Reasons for Divergences within the Ummah}

Numerous reasons could be advanced for divergences among the Ummah in Nigeria, some of which are discussed below.

\section{Political discord about succession}

Cases of Imamship tussles have torn many Muslim communities apart. Some families who believed that their great grandfathers were the harbingers of Islam to a particular town would want to retain the position of the Imam in their family. In short, the question of whether the position of Imam should be by heredity or by appointment of competent persons regardless of family connections still remains unanswered in the Nigerian Muslim community. Instances where the hereditary approach is being challenged have led to rancour to the extent that the central mosques have to be under lock and key for months. This is true of some towns in Yorubaland like Okuku, Obaagun, Offa and Ila-Orangun where cases of disputes over Imamship are still in court.

Closely related is a situation where traditional rulers assume the duty of Imam maker, appointing their favourite candidates as the Imam without due consultation. This is true of Ajase-Ipo, Kwara State, where the traditional ruler of the town, Oba Alebiosu II, was said to have imposed one Muqadam Mustapha as Acting Chief Imam of the town. This was not appreciated by the Muslim community of the town, who saw the action as a deviation from the traditional way of appointing the Chief Imam in the community, which was through recommendation by the Ratibi Imams. ${ }^{13}$ Such was also the situation in Offa where a group of Muslim scholars objected to the imposition of an Imam on them by the "king" of the town. The Path, a monthly magazine of the Islamic Movement, has this to say with particular reference to the Offa imamship dispute: 
Such issues as the involvement of traditional rulers and money-bags in the affairs of the mosque especially as it affects the appointment of Imams and in other vital decisions should be recognised as a keg of gunpowder on which many Muslim communities are currently sitting especially in the Southwest of the country, considering the present wave of Islamic awareness surging through the land. ${ }^{14}$

On the influence of party politics on Muslim unity in Nigeria, many Muslims are attached to partisan politics to the point of sacrificing their religion. In the history of Muslim involvement in politics in Nigeria, it has been observed that the Southern Muslims were ready to ally in politics with their Northern Muslim counterparts, with a body called the Muslim Congress of Nigeria (M.C.N.) being formed in 1948. Unsatisfied with the non-appointment of Muslims into ministerial and other public posts in the first election held in the early 1950s, the M.C.N decided to become a full-fledged political party called the National Muslim League (N.M.L). But this proposal was said to have been foiled by Chief Obafemi Awolowo, a Christian politician in the South-western Nigeria, who set up a parallel Muslim group to counter the first group and actually solicited governmental sanctions against the Muslim party. ${ }^{15}$ Muslims now belong to different political parties and are ready to support non-Muslim candidates against their Muslim rivals.

That political affiliation has been used as an instrument of polarisation amongst Muslims is also substantiated by what transpired in the Offa Muslim community where one AlHaji Jimoh Arowasi was appointed as the Chairman of the Offa Muslim Council and was later removed and replaced with AlHaji Sani Aba Balogun. While the former was a loyalist of the then unpopular political party in Kwara State, the Unity Party of Nigeria (U.P.N), the latter was a loyalist of the then ruling National Party of Nigeria (N.P.N). The removal of AlHaji Arowasi and his replacement with AlHaji Sani Aba was therefore given a political undertone and this consequently divided the Muslim community into factions. The formation of a group called Musulumi nfalafia (Muslims want peace) occurred subsequently. Members of the group left the mainstream Muslim community to found their own separate central mosque and Eid praying ground. ${ }^{16}$

There was also a case where a mere misunderstanding between the Chief Imam and the ruling king of a town on the issue of translation of the Friday Khutbah caused rancour and pandemonium in the Muslim community. It was believed that this minor misunderstanding led to a major crisis in Ajase-Ipo to the point that the king's prestigious palace and flashy cars were burned to ashes by those believed to be supporters of the Chief Imam. ${ }^{17}$ The Muslim community became divided: the Central mosque was under lock and key for months, while a prominent and 
flourishing Arabic school in the town was closed down. The intervention of the State Government in the crisis through the State's Shari'ah Court of Appeal, and the death of the monarch, eventually brought an end to the crisis. ${ }^{18}$

\section{Tribal superiority}

Disunity among Nigerian Muslims can be seen in the differences between the Northern and Southern Muslims. It is disheartening to note that tribal sentiments have been given such religious colouration that rarely would an Hausa Muslim condescend to pray behind a Yoruba Imam. In his study of the reasons for the North's discrimination against the Yoruba with reference to Islamic leadership, AbdulFattah identified some contributory factors which include the Yoruba Muslims' acts of syncretism, their involvement in Christian and atheist ceremonial rites, their un-Islamic marriage contracts, especially courtship for a long period, their congregational supplications after salat and their predetermination of dates for Islamic festivals and celebrations, among others. ${ }^{19}$

The spirit of tribalism has grown to such an extent that Muslims no longer speak with one voice in the country. While the League of Imams and Alfas is operating independently in the southwest, the Supreme Council for Islamic Affairs operates in the northern part of the country. Playing on racial differences has been considered a bane to national integration, which does not benefit any community involved. Buttressing this assertion, Oladosu submits:

Aside from the fact that the essentialisation of race runs into conflict with the vision of Allah in creating humanity into tribes and nations, it conveniently ignores the fact of history that no human civilization, be it Roman, the Persian or even the Muslim, was ever established nor did anyone ever thrive and prosper on the superiority of one race over the other. Historians have even discovered that the prosperity of Europe was a product of an amalgamation of cultural and econo-political elements deposited by races and tribes other than the Europeans themselves. The plenitude ... enjoyed by the United States in all aspects of human life takes this argument beyond any reasonable doubts. ${ }^{20}$

\section{Multiple interpretations of some Qur'anic verses and Prophetic traditions}

The differing interpretation of some verses of the Qur'an by the companions of the Prophet has exacerbated the doctrinal disparity among the ummah. In the same vein, some sayings of the Prophet are open to many interpretations and applications, based on the understanding of the Companions. A very good example of this is the issue of sighting the moon before the commencement and breaking of Ramadan fast as mentioned by the Prophet. To this, a group of Muslims uphold that the commencement and termination of the fast are based on an individual community's independent sighting of the new moon, while another 
group upholds that its appearance and sighting elsewhere in the world makes the fast compulsory. Still another group believes that all and sundry must sight the moon before commencing the fast, while Imam Malik, Imam Shafi $i$ and several others maintain that the fast could commence with the sighting of the moon by only two trustworthy male Muslims. For this multiple interpretation of the ahadith on sighting of new moon, the uniformity of commencing or terminating the Ramadan fast has become a pipe dream in Nigeria up till now.

Apart from the above, the hadith which enjoins a Muslim to change any abomination he sees with his hand, tongue or heart was relied upon by the leader of the Izalah group, Mallam Ismaila Idris. He was said to have based the action of the group against the Sufis on this saying and so was bent on fighting the Sufis to the point of death. ${ }^{21}$

\section{Cultural and Doctrinal Interference}

If the Arabs who had lived and observed the Prophet (PBUH) first-hand could slip back to their former pre-Islamic practices soon after the death of the Prophet, then no one can doubt that those who accepted the religion from other places could not easily forget their cultural background as well as the doctrinal principles of their former religion. They thus mixed up their former religious and doctrinal practices with the new religion they embraced. There was the fact that Islam had spread far east and west towards the end of the Umayyad period and various people of various cultures had embraced Islam. These people of different cultural backgrounds therefore enriched Islamic teachings with their culture. This practice is rampant among some Yoruba Muslims who see nothing wrong with the participation of Muslims in traditional festivals because such are regarded as mere celebration of cultural heritage. There was a case in Offa where one AlHaji Shehu Sambaliyu Popo was said to have preached vehemently against Muslims' participation in the Onimaka festival on one Friday during Juma'ah sermon. He was said to have been met with strong opposition by some Muslims who held that:

rather than being idol/hero worship described as shirk in Islamic parlance, the whole activities of the whole Onimaka festival should be seen as celebration of cultural heritage which is without any consequence in Islam and therefore be allowed. ${ }^{22}$

\section{Integration approaches of Islam}

Islam promotes national integration and international understanding by tracing man to a single soul and emphasising the equality of all people. The Qur'an traces mankind to a single soul from whom his partner was generated and from the two, all nations were raised. However, the Qur'an does not ignore that people may be 
influenced by ethnic, tribal or linguistic affiliation; hence, it calls their attention that these differences are meant for identification only. No wonder then that Allah declares that "this Ummah of yours is a single Ummah and I am your Lord and Cherisher: Therefore fear Me" (Q, 22:67). The Prophet himself reminded people that superiority should not be made on the basis of colour, as they all are from the same source. He was reported to have warned:

Let there be no preference of an Arab over a non Arab or of a non Arab on Arab, neither of the red skinned over the black, nor of the black skinned over the red except by righteousness ... You all belong to Adam, and Adam is made out of dust (narrated by Ahmad).

To substantiate the above, the Qur'an emphatically disapproves of unnecessary discrimination made among the Prophets of Allah, stressing that they all belong to one family:

Say! We believe in God, and the revelation given to us, and to Ibrahim, Isma'il, Ishaq, Ya'qub and the tribes, and that given to Musa and Isa and that given to all (Prophets) from their Lord, we make no difference between one and another of them, and we bow to God (in Islam) (Q, 2:136).

As part of the measures to promote national integration, religion regulates business between human beings for the purpose of encouraging productive business transactions and ensuring functional socio-economic relations between them. As such, trading in unlawful goods, hoarding, exploitation, usury, buying stolen properties, withholding full measure and interest, are seen as threats to national peace and are condemned in clear terms. Such Islamic financial products as musharakah, mudharabah and others which encourage business partnerships are meant to promote mutual socio-economic integration among Muslims. Giving a vivid attestation to the role of the Islamic economic model to the unification of society with particular reference to Africa, a scholar stated:

Islam is reputed for introducing a measure system into the African continent through the muddu (equivalent to about 50 centilitres) and Sa'a (equivalent to about 1 litre), measurements which gained currency during the waves of Islamic resurgence which overwhelmed the continent in the $18^{\text {th }}$ century. ${ }^{23}$

Apart from enjoining virtue as a means of promoting national integration, such acts as vandalism, violence, theft, prostitution, adultery, false witness, looting, usury and murder, which are a bane to peaceful co-existence in the community, are condemned in Islam as they can lead to disintegration. In other words, unjust dealings, oppression, lies, and other means of misappropriation of another's property adversely affect national integration. 
The command that the five daily prayers be said congregationally is intended to promote peaceful co-existence among Muslims. In the mosque, individuals stand side by side with no discrimination whatsoever. This same service is organised at a wider forum every Friday when devotees congregate to observe Juma'at services. The annual Eidil fitr and Eidil adha also create other forums for the same purpose. Here, everybody performs the same duty and shares pleasantries among themselves irrespective of colour, nationality or race. In the same vein, the annual pilgrimage to Makkah and Madinah indicates a vibrant Islamic commonwealth of nations where all nations, tribes, races, and colours converge to perform the same rites, put on the same uniform, and utter the same words at the same time in the same place. No other forum could bring or has brought mankind together as does the hajj. The institution of hajj breaks all forms of discrimination and enhances mutual cooperation, respect, love, assistance and brotherhood. All marks of discrimination and distinction between colours and races are removed. Such a trans-national character impressed Malcolm X, who declared: "The people of all races, colours, from all over the world coming together as one! It has proved to me the power of the One God." ${ }^{4}$

The institution of zakat in Islam is equally an effective weapon of strengthening unity between the rich and the poor. It facilitates transfer of some resources from the rich to the poor and thus contributes to the realisation of social objectives.

Understanding the fact that differences could lead to chaos at times, Islam provides a mechanism for resolving such differences amicably through a third party. The Qur'an for instance says:

If two parties among the believers fall into a fight, make ye peace between them: but if one of them transgresses beyond bounds against the other, then fight ye (all) against the one that transgresses until it complies with the command of Allah. But if it complies, then make peace between them with justice and be fair; for Allah loves those who are fair (and just). The believers are but a single brotherhood. So make peace and reconciliation between your two (contending) brothers; and fear Allah, that ye may receive mercy (Q, 49:9-10).

The bottom-line of what we are saying is that the nature of human beings makes them susceptible to dispute and misunderstanding. But with the knowledge with which they are endowed, they should be able to learn how to live peacefully and settle their differences amicably.

The spirit of Islamic brotherhood and unity is further stressed in its disapproval of physical fighting or taking up arms against each other. Muslims are forbidden to murder another Muslim or even point a weapon at each other. Therefore, should Muslims in various warring towns or countries realise this, they would not have participated in any religious or ethnic crises. Muslims in Ile-Ife would 
then realise that they would be taking up arms against their Muslim brethren in Modakeke; while Muslims from Erin-ile would understand the enormity of their participation in communal conflict against Offa.

Adebayo cited an instance where the sense of Islamic brotherhood was demonstrated to the core by the Muslim Hutu and Tutsi populations of Burundi and Rwanda who did not participate in the wars of the two countries. Rather, they engaged in stopping the violence and in peace making. ${ }^{25}$ This was the finding of a candidate's Ph.D. dissertation with the Institute of Conflict Analysis and Resolution (ICAR) at George Mason University. In an excerpt of the finding he writes:

While briefly in Rwanda, and for a few weeks in Burundi, I encountered a sizeable population of Muslims, who lived among a majority of Christians. I was curious about the connection of those people's ethnic and religious identities. I thought for a while that, perhaps, Muslims were made of ethnic groups other than Hutus and Tutsis. I was quickly corrected; Muslims too were mainly either Hutus or Tutsis. This raised the question of how they handled themselves during the ethnic war. The response I received from Muslims in Rwanda and Burundi was that because they were Muslims they should not, and could not fight each other, or fight others, because of ethnic differences; Islam, they said, prohibited that ... In order to validate this story I asked professionals working with the United Nations and other western NGOs if they knew about that "phenomenon". Everyone I enquired from responded positively that it was true that the Muslim population refrained from participation in the war and that the Muslim sections of Kigali and Bujumbura were safe havens during the war. ${ }^{26}$

The above shows a clear demonstration of the spirit of Islam in ensuring unity among themselves in spite of their divergences, and how Muslims should comport themselves and hold fast to the rope of Allah, demonstrating their brotherhood in the face of adversity, chaos and crises.

\section{Conclusion and Recommendations}

Divergence is a common characteristic of mankind, and in fact a design of Allah. It is obviously not an oversight on His part to have created us in a diverse manner in terms of differences in environment, tribe, clan, language, colour and even religion. The Qur'an has in its wisdom declared that if it had been the wish of Allah, He could have made mankind speak the same language, profess the same religion, belong to same environment, tribe or clan, and among others, have the same colour. Diversity therefore is a natural phenomenon which is inevitable for human existence. However, rather than for these diverse entities to unite for the purpose of reaping the fruit of diversity, it seems nations are being carried away by 
the spirit of tribalism and other differences to perpetuate evil. It is more pathetic that disunity has shaken the Muslim ummah to its root so that the teachings of Islam on it have been downplayed for personal or community interest.

If Muslims in Nigeria would therefore abide by the Qur'anic injunction that they should hold fast to the rope of Allah and avoid division among themselves (Q, 3:103), and to contribute meaningfully towards national and universal integration, we strongly feel that it would not be too much for them to consider the following recommendations:

- An annual conference on Muslim unity and brotherhood where issues on national integration can be extensively discussed should be organised by some umbrella bodies such as the National Council of Muslim Youths Organisations and the Supreme Council for Islamic Affairs.

- The Nigeria Supreme Council for Islamic Affairs should set up a committee that will compile lists of all Islamic organisations, groups, brotherhood and sects. This will provide the Council a database of all Muslim organisations, their aims, objectives, philosophy and mode of operation. Adequate records of the leadership of each of the organisations, their headquarters and branches should be kept. Any organisation that fails to register with the Council should be publicly declared non-compliant, which organisation would then become suspect in the case of any unruly activities and behaviour in the country.

- Different Islamic groups and sects should come together to iron out differences and realise that in spite of their differences, there is still room for cooperation and unity. If they fail to do this, it will be easy for their enemies to infiltrate them and cause dissension.

- The indiscriminate proliferation of central mosques, Eid praying grounds and Muslim organisations has not been helpful to the Ummah in Nigeria; hence, certain criteria should be put in place to be met by those who have genuine reasons to initiate such.

- The appointment of Imams should be the exclusive responsibility of learned Muslim scholars in a community and not for any traditional ruler or the wealthy to impose their will or influence. This is not saying they should not be involved; indeed it is preferable to receive the royal blessing for any appointment that has emanated from the League of Alfas in the community.

Should the Nigerian Muslims decide to unite under the umbrella of Islam, the agitation for national Muslim integration will not only be achieved, but it may also encourage global integration. 


\section{Notes}

* Rafu Ibrahim Adebayo is a lecturer in the Department of Religions, University of Ilorin, Nigeria, from where he also obtained his $\mathrm{PhD}$ in Islamic Studies. His area of specialisation is Islamic Thought with special interest on Islamisation of Knowledge Programme and contemporary issues.

1. A. Raheem, Islamic History (Lagos: Islamic Publications Bureau, 1983), 90-94.

2. O. Abdul Fattah, Islam in Nigeria - One Crescent Many Focuses (Maiduguri: Sakirabe Publishers, 2007), 46.

3. Ibid., 48.

4. Ibid., 99.

5. Mallam is a man learned in Qur'anic studies.

6. Y.A. Quadri, "An Examination of the Emergence of the Tijaniyyah in Nigeria", Journal of Nigerian Association of Teachers of Arabic and Islamic Studies (NATAIS), vol. 2, no. 2, 1983, 76-80.

7. See Y.A. Quadri, The Sayings of the Prophet (S.A.W) Annotated Translation from Arabic into English (Ijebu-Ode: Shebiotimo Publication, 1995), 4.

8. Y.A. Quadri, "A Study of the Izalah: A Contemporary Anti-Sufi Organisation in Nigeria", Orita- Ibadan Journal of Religious Studies, vol. XVII, no. 2, Dec. 1985, 95-106.

9. The Tablighi Movement owes its development to the Sufi teachings and practices of Shaykh Ahmad Sirhindi, Shah Wali Allah and Sayyid Ahmad Shahid, the founder of the Mujahiddin movement. The Movement was founded in 1926 by a Sufi scholar, Maulana Muhammad Ilyas (1885-1944). For more on this, see L.F. Oladimeji, “The Tablighi Movement and Jehovah's Witnesses in Nigeria: A Comparative Analysis of their Propagation Strategies" in Z.I.Oseni, (ed), Fluorescence of Arabic and Islamic Studies in Nigeria (Festschrift in Honour of Professor Wahab O.A. Nasiru (Ibadan: HEBN Publishers Plc., 2008), 90-99.

10. A.A. Oladosu, "On Muslim Unity: Theory, Philosophy, Reality", Hikmah Journal of Amin Research and Cultural Centre, vol. 1, no. 1, 2011, 23.

11. MUSWEN Strategic Plan (2012-2015). Being Presentation of Reports of The Companion's MUSWEN Strategic Retreat, held from January 27-29, 2012 at University of Ibadan Conference Centre, 10.

12. Ibid.

13. N.Y. Raji, "Religion and Traditional Institution: Effects of Power Tussle between Olupo and his Chief Imam as a Case Study." A paper presented at the $29^{\text {th }}$ Annual Conference of the Nigerian Association for the Study of Religions (NASR) held between $2^{\text {nd }}$ and $5^{\text {th }}$ September, 2008, 4.

14. See anonymous, "Onimaka, Tearing Offa Apart" in The Path, vol. 4, no. 6 Shawwal 1424 (December 2003), 15.

15. O. Abdulfattah, "Unity and Brotherhood Amongst Muslim Communities in PostIndependence Era in Nigeria". A paper presented at an International Conference organised by the Department of Arabic and Islamic Studies, University of Ibadan, 2010,9 .

16. Anonymous, "Onimaka, Tearing Offa Apart", 10-15.

17. N.Y. Raji, 11.

18. Ibid. 
19. O. Abdul Fattah, 55-57.

20. A.A. Oladosu, 7.

21. Y.A. Quadri, "A Study of the Izalah", 101.

22. Anonymous, "Onimaka, Tearing Offa Apart", 9.

23. O. Abdulfattah, "Unity and Brotherhood Amongst" 2.

24. D.J. Berggren, "More Than the Ummah: Religious and National Identity in the Muslim World", American Journal of Islamic Social Sciences, vol. 24, no. 2, Spring 2007, 73.

25. R.I. Adebayo, "Strategising Peace Through Islamic Ethical Values", in I.O. Albert and I.O. Oloyede, (eds), Dynamics of Peace Processes (Ilorin: Centre for Peace and Strategic Studies, 2010), 30-31.

26. Ibid. 